\title{
Horticultural

\section{Effect of different nutrition levels and seasons on nutrient uptake of lawn grass Cynodon dactylon}

\author{
Prarthana Gogoi*, Pradip Mahanta and Madhumita C. Talukdar \\ Department of Horticulture, Assam Agricultural University, Jorhat-785013, Assam, India
}

\begin{abstract}
Proper nutrient management improves the green colour and shoots density which is frequently used as a quality determination parameter in lawn. Fertilizers should be applied according to a lawn fertilization schedule. Too little fertilizer results in thin, sometimes yellowing turf. So an appropriate fertilizer should be used to maintain the deep colour, high density, uniformity, early green up and late fall colour retention. No systemic and scientific work has been identified with regard to nutrition of grass species. So far Assam is concerned not much research work has been conducted on standardization of optimum nutrient levels for proper growth and quality of Cynodon dactylon. Therefore field experiments were conducted with an objective to determine the effect of nutrient levels and seasons on nutrient uptake of lawn grass C. dactylon in both local and hybrid cultivar under Assam conditions. The seven treatments comprised of T0 Control, T1 -Vermicompost 200g/m², T2- Vermicompost 200g/m² + 10:10:10gm/m2 (N:P:K), T3-Vermicompost 200g/m² $+20: 20: 20 \mathrm{gm} / \mathrm{m} 2(\mathrm{~N}: \mathrm{P}: \mathrm{K}), \mathrm{T} 4-40: 40: 40 \mathrm{gm} / \mathrm{m}^{2}$ (N:P:K), T5 - 50:50:50 gm/m² (N:P:K) and T6 - 60:60:60 gm/m² (N:P:K). The results revealed that T6 exhibited highest amount and T0 contained lowest amount of N, P and $\mathrm{K}$ in the shoot tissue. The highest $\mathrm{N}$ contents of (5.055\%), P (0.415\%) and K (2.470\%) were observed in the month of February'14. While the lowest N (2.567\%) was in the month of July'13 and P (0.287\%), K (1.267\%) was observed in the month of August'13. Among the cultivars, the hybrid cultivar exhibited more N, P and K in all the months. More uptake of nutrient is required to maintain the quality parameters i.e. proper denseness, aesthetically pleasing colour etc.
\end{abstract}

\section{KEY WORDS: CYNODON DACTYLON, LAWN GRASS, TURF}

\section{INTRODUCTION}

The turf is an integral and significant part of the landscape and enhances its beauty when established properly, while a poor turf will detract from the overall appear- ance (Brede, 2000). Proper management of turf grass can lead to an aesthetically beautiful turf. Cynodon dactylon is one of the major turf grass grown for aesthetic as well as recreational purposes. Bermuda grass, Cynodon spp. is one of the most commonly grown turfgrass genera

\author{
ARTICLE INFORMATION: \\ *Corresponding Author: prarthana.piku246@gmail.com \\ Received $5^{\text {th }}$ Feb, 2016 \\ Accepted after revision $28^{\text {th }}$ March, 2016 \\ BBRC Print ISSN: 0974-6455 \\ Online ISSN: 2321-4007 \\ Ainitionson Reuters ISI SCI Indexed Journal \\ NAAS Journal Score : 3.48 \\ - A Society of Science and Nature Publication, 2016. All rights \\ reserved. \\ Online Contents Available at: http//www.bbrc.in/
}


in the southern United States having excellent drought tolerance (Jeffrey et al. 2015).

The demand for the use of Bermuda grass as a turf grass is abundant and historical. Bermuda grass (Cynodon dactylon) is a warm-season turfgrass and is widely used on home lawns, golf courses, and sport fields. Bermuda grass is very wear resistant among the warm season turfgrasses and has an excellent recuperative capacity. Cynodon dactylon is further spread through its commercial use as forage and turf, being widely used in the Sonoran Desert region as a lawn grass, (Chambers and Hawkins, 2002, Turgeon, 2002).

Beyond practical purposes, the turf has helped to beautify many parks and landscapes, while also providing resilient playing fields for many sports. In addition to sports such as football and soccer, Bermudagrass is a desirable playing surface for numerous other activities, including polo fields and horse racing tracks, ( Patton et al., 2004 and Bloodhorse, 2005). Presently, its hybrids are used extensively as lawn grasses (Usher, 1974). It also has been used in soil stabilization projects for preventing soil erosion (Anderson, 1999). Hence, the present investigation on the nutrient uptake of Bermudagrass was undertaken with a view to find the optimum nutrient levels under which maximum nutrients are consumed to maintain a proper quality turf.

\section{MATERIAL AND METHODS}

The experiment was conducted in Department of Horticulture, Assam Agricultural university during 20132014 on Bermuda grass (both local and hybrid cultivars). The treatments included of $\mathrm{T}_{0}-$ Control, $\mathrm{T}_{1}$-Vermicompost $200 \mathrm{~g} / \mathrm{m}^{2}, \mathrm{~T}_{2}-$ Vermicompost $200 \mathrm{~g} / \mathrm{m}^{2}+10: 10: 10 \mathrm{gm} /$ $\mathrm{m}^{2}(\mathrm{~N}: \mathrm{P}: \mathrm{K}), \mathrm{T}_{3}$-Vermicompost $200 \mathrm{~g} / \mathrm{m}^{2}+20: 20: 20 \mathrm{gm} / \mathrm{m}^{2}$ $(\mathrm{N}: \mathrm{P}: \mathrm{K}), \mathrm{T}_{4}-40: 40: 40 \mathrm{gm} / \mathrm{m}^{2}(\mathrm{~N}: \mathrm{P}: \mathrm{K}), \mathrm{T}_{5}-50: 50: 50 \mathrm{gm} /$ $\mathrm{m}^{2}(\mathrm{~N}: \mathrm{P}: \mathrm{K})$ and $\mathrm{T}_{6}-60: 60: 60 \mathrm{gm} / \mathrm{m}^{2}(\mathrm{~N}: \mathrm{P}: \mathrm{K})$.The experiment was laid out in a split plot design with 3 replication having a plot size of 1.5 square meter. The sources of nitrogen, phosphorus and potassium were urea, single super phosphate and muriate of potash, respectively. The different doses of vermicompost, nitrogen, phosphorus and potash applied with their treatment combinations. The remaining half nitrogen was splitted into three parts and applied during the month of August, November and February as foliar spray. The planting materials of local type required for the study were collected from the healthy mother plant from Horticultural orchard of Assam Agricultural University.

The hybrid cultivar was collected from Kaziranga Golf Resort. Sprigs of 3-4 nodes were planted at a spacing of $7 \mathrm{~cm} \times 7 \mathrm{~cm}$ by dibbling method. The plots were lightly irrigated just after planting. All the aftercare and intercul- tural operations like mowing, rolling, racking and weeding were performed at regular interval. Treatment wise above ground plants were collected at each month and were then chopped into small pieces and sun dried as well as oven dried at $60-65^{\circ} \mathrm{C}$ to a constant weight, powdered and stored in a sealed polythene bag for $\mathrm{N}, \mathrm{P}$ and $\mathrm{K}$ analysis. The amount of nitrogen was expressed as percentage on dry weight basis. $0.5 \mathrm{mg}$ of sample was taken in a digestion flask to which digestion mixture was added and the sample was digested with $25 \mathrm{ml} \mathrm{of} \mathrm{H}_{2} \mathrm{SO}_{4}$ till a bluish liquid is formed. This digested solution was used for estimation of total nitrogen by Micro-Kjeldahl's method described by Humphries (1956). $\mathrm{N}$ was estimated as the amount of ammonia evolved during steam distillation of the digest.

For phosphorus estimation, plant samples were digested by the wet digestion method as described by Jackson (1973). $0.5 \mathrm{~g}$ of plant sample was taken in a 250 $\mathrm{ml}$ conical flask and $5 \mathrm{ml}$ of conc. $\mathrm{HNO}_{3}$ was added to it. After pre digestion with nitric acid, $10 \mathrm{ml}$ of triacid mixture $\mathrm{HNO}_{3}, \mathrm{H}_{2} \mathrm{SO}_{4}$ and $\mathrm{HClO}_{4}$ in the ratio of 10: 1:4) was added to the conical flask and digested on hot plate at temperature between $200-250^{\circ} \mathrm{C}$ till yellow fumes were removed and about $2 \mathrm{ml}$ of the solution was left. The solution was then used for determination of leaf phosphorus by adopting colorimetric method. The stock solution prepared for determination of leaf phosphorus was used for estimation of leaf potassium by using flame photometric method (Jackson, 1973).The experimental data obtained from various observations were analysed statistically by using Fisher's method of analysis of variance in spilt plot design as described by Panse and Sukhatme (1978).

\section{RESULTS AND DISCUSSION}

The significant increase of $\mathrm{N}$ content was detected with gradual increase in nutrient levels as evidenced from the table 1. Regarding month wise, $\mathrm{N}$ content was found in a decreasing trend from the month of April'13 to July'13. Thereafter it was increased from the month of August'13 onwards, followed by increased in the month of March'14. Among the treatments $\mathrm{T}_{6}$ exhibited the highest and treatment $\mathrm{T}_{0}$ exhibited the lowest amount of $\mathrm{N}$ in the shoot tissue. The highest $\mathrm{N}$ content $(5.055 \%)$ was obtained in the month of February'14, followed by next higher level (5.046\%) in the month of January'14 in treatment $T_{6}$ and they were at par, while in February'14 treatment $\mathrm{T}_{0}$ recorded $(3.461 \%)$ and in January $(3.454 \%)$ of $\mathrm{N}$ in shoot. The lowest $\mathrm{N}$ content $(2.567 \%)$ was observed in the month July'13, followed by August'13 (2.675\%) in Treatment $\mathrm{T}_{0}$.

Cultivar effects on the per cent $\mathrm{N}$ content during the different months were found to be significantly different. Among the two cultivars $\mathrm{C}_{2}$ exhibit more $\mathrm{N}$ content 


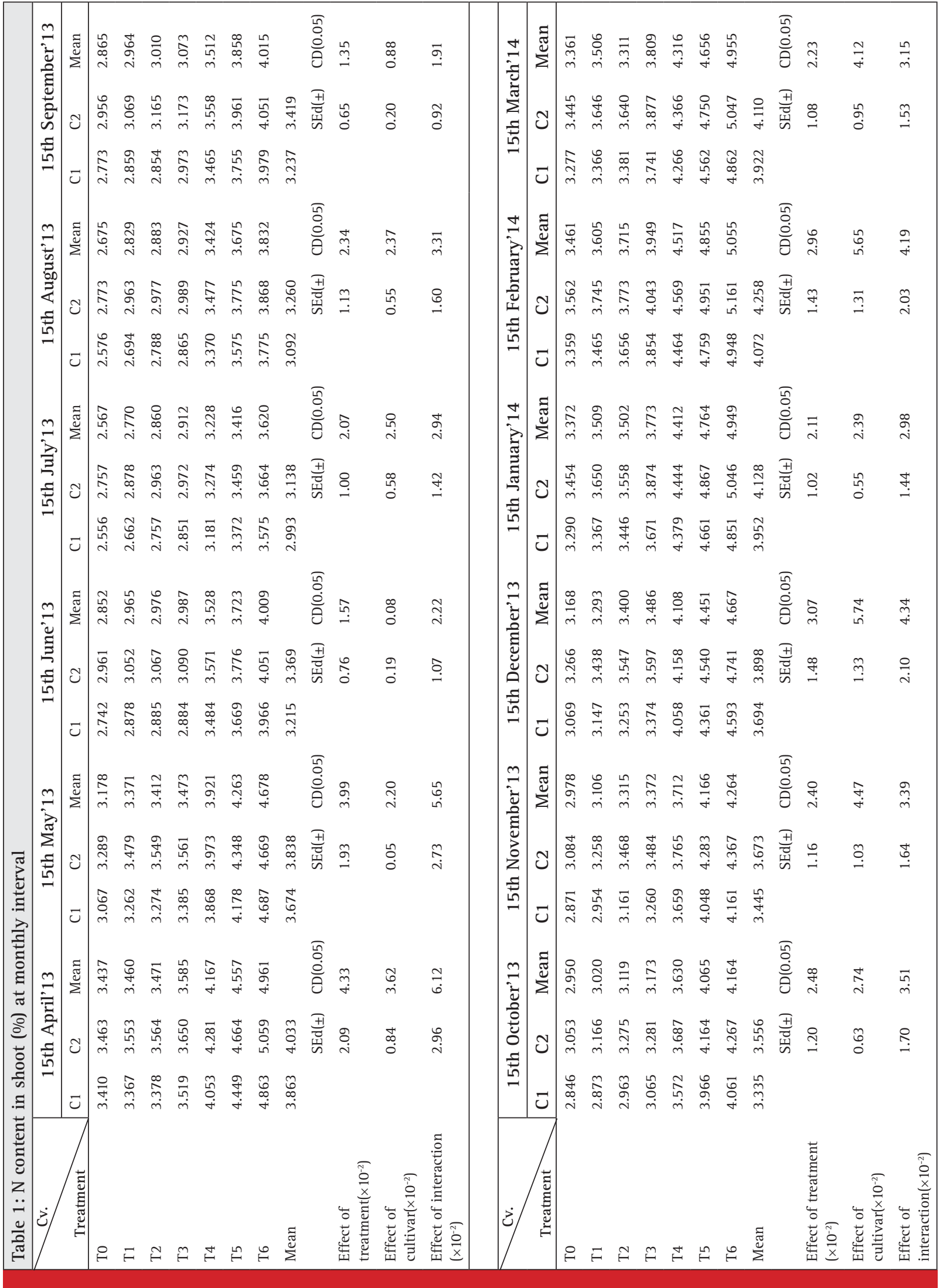


in all the months. The decreasing trend of $\mathrm{N}$ per cent was observed from the month of April'13 to July'13, followed by increased from the month of August'13 onwards.

This might be due to more availability of nutrients which reduced carbohydrates and thereby more nitrogen accumulation in shoots. Earlier Monore et al. (1967) and Singh et al. (1992) obtained more per cent nitrogen in shoot tissue with an increased level of nitrogen. Hence, the findings of the present investigations are in conformity with the findings of the above scientists. The highest per cent nitrogen content was obtained in the month February'14. This might be due to application of the splits of nitrogen in February'14 and less leaching as well as more mineralization of organic nitrogen. Powell et al. (1967) and Singh et al. (1992) have reported similar trend of findings in Kentucky bluegrass and Cynodon dactylon (L.) Persoon. The lowest per cent content was obtained in the month of July'13. This might be due to leaching loss and dilution effect due to increase in fresh weight of clipping. Singh et al. (1992) also reported decrease in per cent nitrogen of tissue during summer month (June and July). Hence, the results obtained in the present investigation are in conformity with the findings of the above workers. More nutrient uptake in spring months than the summer months was observed by Brink et al. (2005)

In cultivar $\mathrm{C}_{1}$ highest $\mathrm{N}$ content (4.027\%) was found in the month of February'14, followed by January'14 (3.952\%). The lowest amount of N (2.993\%) was found in the month of July'13 followed by August'13 (3.092\%). Again in cultivar $\mathrm{C}_{2}$ highest amount (4.258\%) was recorded in the month of February'14, followed by January'14 (4.128\%). The lowest amount was found in the month of July'13 (3.138\%), followed by August'13 (3.260\%).

Data on per cent $\mathrm{P}$ content in shoot in Table 2 revealed that there was a significant increase in $\mathrm{P}$ content with increased concentration of nutrients. Regarding month wise $\mathrm{P}$ content was found in a decreasing order from the month of April'13 to July'13. Thereafter it was increased from the month of August'13, followed by decreased in the month of March'14. Among the treatments $\mathrm{T}_{6}$ exhibited highest and treatment $\mathrm{T}_{0}$ exhibited lowest amount of $\mathrm{P}$ in the shoot tissue. The highest $\mathrm{P}$ content $(0.415 \%)$ was obtained in treatment $\mathrm{T}_{6}$ in the month of February'14, followed by next higher level (0.397\%) in the month of January'14. The lowest P content (0.287\%) was observed in the month August'13 in treatment $\mathrm{T}_{0}$ followed by treatment $\mathrm{T}_{1}(0.290 \%)$. Among the two cultivars $\mathrm{C}_{2}$ exhibit more $\mathrm{P}$ content in all the month's observation.

Beaty et al. (1960) reported similar findings of increasing trend of phosphorus content with a gradual increase in levels of nitrogen. Hillard et al. (1992), Rechigl (1992), Robinson and Ellers (1996), also reported that addition of phosphorus fertilizer increased phosphorus concen- tration in the Rye grass. This might be due to more vigorous growth of roots and shoots, which enhanced the uptake of phosphorus. Again in blue grass per cent phosphorus was increased by increasing potassium levels. The highest per cent phosphorus content of tissue $(0.377 \%)$ was obtained in winter season particularly in February month in cultivar $\mathrm{C}_{2}$, which might be due to mineralization of organic form of phosphate. The lowest per cent of phosphorus content was observed in summer season might be associated with dilution effect of highest weight of clipping. Powell et al. (1967) and Monore et al. (1967) also reported the similar trend of results in per cent phosphorus content. Hence, the results obtained in the present investigation are in conformity with the above workers.

In cultivar $C_{1}$ highest $P$ content $(0.370 \%)$ was found in the month of February'14, followed by January'14 (0.363\%). The lowest amount of P (0.306\%) was found in the month of August'13 followed by July'13 (0.306\%). Again in cultivar $\mathrm{C}_{2}$ highest amount (0.377\%) was recorded in the month of February'14, followed by January'14 (0.368\%). The lowest amount of P was found in the month of August'13 (0.306\%), followed by July'13(0.306\%).

Data on per cent $\mathrm{K}$ content in shoot revealed that there was a significant increase in $\mathrm{K}$ content with increased concentration of nutrients (Table 3). Regarding month wise $\mathrm{K}$ content was found in a decreasing order from the month of April'13 to July'13. Thereafter it was increased from August'13 onwards, followed by decreased in the month of March'14. Among the treatments $T_{6}$ exhibited highest and treatment $\mathrm{T}_{0}$ exhibited lowest amount of $\mathrm{K}$ in the shoot tissue. The highest $\mathrm{K}$ content $(2.470 \%)$ was obtained in the month of February'14, followed by next higher level $(2.440 \%)$ in the month of January'14 in treatment $\mathrm{T}_{6}$, The lowest $\mathrm{K}$ content in treatment $\mathrm{T}_{0}(1.267 \%)$, followed by treatment $\mathrm{T}_{1}(1.275 \%)$ in the month August'13 and which were at par.

This is in line with Adane et al (2003) who reported that the nutrient of natural grass lands increases with increasing levels of N, P, K fertilizer application. Potassium concentration in tissues in response to potassium fertilization is nitrogen dependent. The lowest per cent potassium content was recorded in control which might de due to less growth of roots and shoots. Beaty et al. (1960) and Monore et al. (1967) in Kentucky blue grass and Webstar et al. (2005) in perennial rye grass also reported the increase in potassium content with an increase in levels of nitrogen. The highest per cent potassium content in both the cultivars was obtained in February. The higher per cent potassium content in winter season (February) might be due to more availability of potassium in soil. The lowest per cent potassium content in July'13 were recorded which might be due to 


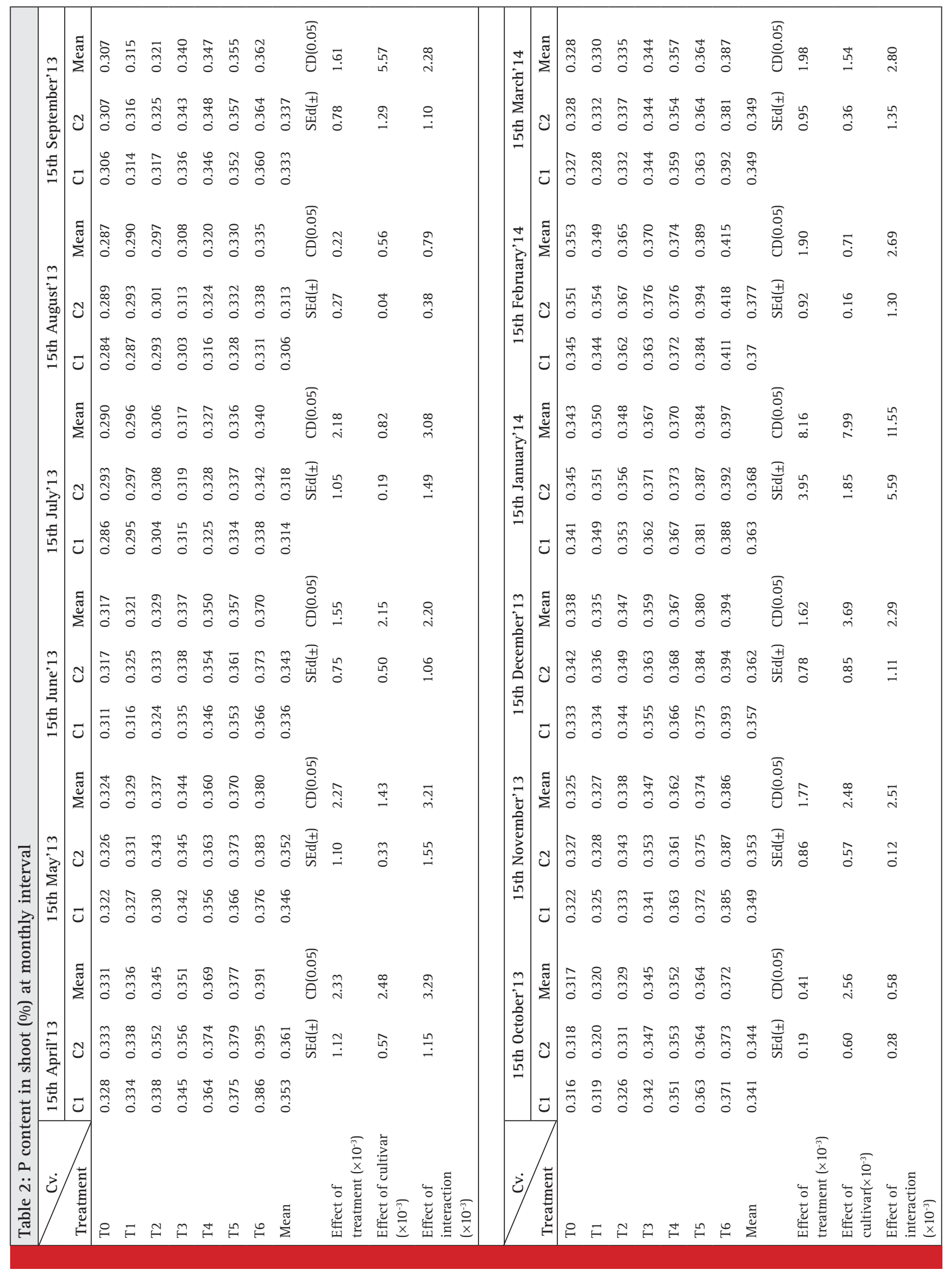




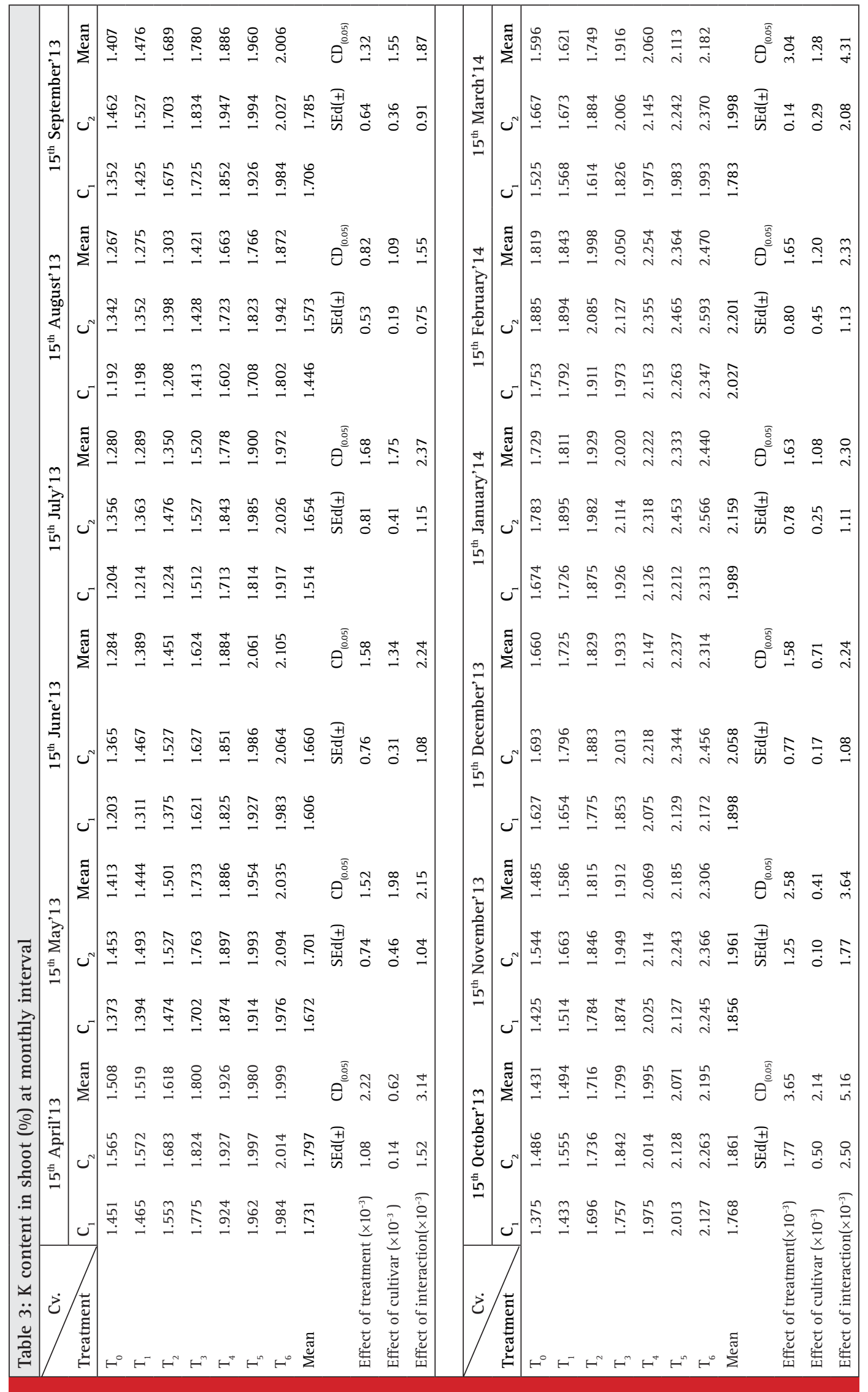


less availability of potassium in soils that were entrapping with clay minerals. The increase in winter in per cent content of potassium and decrease in summer in the present investigation are in conformity with the findings of Beaty et al. (1960) and Powell et al. (1967).

Among the two cultivars $\mathrm{C}_{2}$ exhibit more $\mathrm{K}$ content in all the months. In cultivar $\mathrm{C}_{1}$ highest $\mathrm{K}$ content was $(2.027 \%)$ found in the month of February'14, followed by January'14 (1.989\%). The lowest amount of $\mathrm{K}(1.446 \%)$ was found in the month of August'13 followed by July'13 (1.514\%). Again in cultivar $C_{2}$, highest amount $(2.201 \%)$ was recorded in the month of February'14, followed by January'14 (2.159\%). The lowest amount was found in the month of August'13 (1.573\%), followed by July'13 (1.654\%).

\section{CONCLUSION}

From the above findings it could be concluded that the nutrient uptake is different according to the different nutrition application and different season. Higher dose of nutrient supply increased the nutrient uptake in both the cultivars and the uptake was found to be more in the winter months.

\section{ACKNOWLEDGEMENTS}

The authors are greatly thankful to the Department of Horticulture, Crop physiology and Soil science for providing the necessary facility and laboratory support for carrying out the study successfully. We are also thankful to Assam Agricultural University for providing for providing research area, funds for conducting this research.

\section{REFERENCES}

Adane, K. and Berhan, T. (2003). Effect of harvesting frequency and nutrient levels on natural pasture in the central highlands of Ethiopia. Trop. Sci. 45: 77-82.

Anderson, W.P. (1999). Perennial weeds: characteristics and identification of selected herbaceous species. Iowa state university press, Ames. Iowa, 228.

Beaty, E.R., McCreery, R.A. and Powell, J.D. (1960). Response of Pensacola bahiagrass to nitrogen fertilization. Agron. J. 52: 453-455.

Bloodhorse.com (2005). New Bermuda grass to debut at Del Mar. Available at: http://racing.bloodhorse.com/viewstory. asp?id=29047. Accessed 8 July 2005.

Brede, D. (2000). Turfgrass Maintenance Reduction Handbook : Sports, Lawns and Golf, Sleeping Bear Press, Chelsa, MI.
Brink, G. E., Pederson, G. A. and Sistani K. R. (2005).Nutrient Uptake of Swine Effluent-Fertilized Bermuda grass During Primary Spring and Summer Growth. Journal of Plant Nutrition 28: $1337-1346$

Chambers, N. and Hawkins, T.0. (2002). Invasive plants of the Sonoran Desert, a field guide. Sonoran Institute, Environmental Education Exchange. National Fish and Wildlife Foundation. Tucson, Arizona. 120

Hillard, J.B.; Haby, V.A. and Hons, F.M. (1992). Annual ryegrass response to limestone and phosphorus on an ultisol. Commun. Soil Sci. Pl. Anal. 23: 175-188.

Humphries, E.C. (1956). Modern methods of Plant Analysis.468-502.

Jackson, M.L. (1973). Soil chemical analysis. Prentice Hall of India Pvt. Ltd., New Delhi.

Jeffrey C. Dunne, W. Casey Reynolds, Grady L. Miller, Consuelo Arellano, Rick L. burg, A. Schoeman, Fred H. Yelverton and Susana R. Milla Lewis. (2015). Identification of South African Bermuda grass Germplasm with Shade Tolerance. Hort science 50:1419-1425

Monore, C.A.; Coorts, G.D. and Skogley, C.R. (1967). Effect of nitrogen and potassium levels on the growth and chemical composition of Kentucky bluegrass. Agron. J. 61: 253-258.

Panse, V.S. and Sukhatme, P.V. (1978). Statistical methods for agricultural workers. ICAR Publication, New Delhi.

Patton, A.J.; Williams, D.W. and Reicher, Z.J. (2004). Establishing seeded Bermuda grass. Research. Science for the golf Course. Environmental Institute for Golf.73-77

Powell, J.D.; Stanley, R.L. and Beaty, E.R. (1967 Effect of clipping height on forage distribution and regrowth of Pensacola bahia grass. Agron. J. 59: 185-188.

Rechcigl, J.E. (1992). Response of ryegrass to limestone and phosphorus. J. Prod. Agric. 5: 602-607.

Robinson, D.L. and Ellers, T.L. 1996. Phosphorus and potassium influences on annual ryegrass production. Louisi. Agric. 2: $10-11$.

Singh, J.; Parmer, A.S. and Kumar, R. (1992). Effect of levels and time of application nitrogen on growth of turf of (Cynodon dactylon L.). Punjab Hort. J. 32: 180-186.

Turgeon, A.J. (2002). Turfgrass management. $6^{\text {th }}$ ed. Upper Saddle River, N.J.: Prentice Hall Company. Reston.

Usher, G. (1974). A dictionary of plants used by man. Constable and Company, Ltd., 10 Orange St., London WC2H 7EG, p. 619.

Usher, G. (1974). A dictionary of plants used by man. Constable and Company, Ltd., 10 Orange St., London WC2H 7EG, p. 619.

Webstar. D.E. and J.S. Ebdon (2005). Effects of nitrogen and potassium fertilization on perennial rye grass cold tolerance during acclimation in late winter and early spring. Hort Sci 40: 842-849 